\title{
Anvendt historie: Fra München- til Vietnam-syndromet
}

\section{Af Niels Bjerre-Poulsen}

Vi historikere ynder at kokettere med, at det vi gør i lige så høj grad er et håndværk, som det er videnskab. Og hvis vi skulle komme i bekneb for argumenter for vores uundværlighed, så kan vi altid citere den spanske filosof George Santayanas ord om, at "den, der ikke kender historien er dømt til at gentage den".

Citatet fra Santayana udlægges som regel som en måde at sige på, at man skal lære af fortidens fejl - men hvilke fejl? Skal historien gøres anvendelig for nutidens beslutninger, må man lede efter relevante historiske paralleller - passende analogier. Er det en særlig del af den politiske beslutningsproces, som historikere kan og bør påtage sig?

Den amerikanske historiker Ernest R. May skrev i 1973 en bog med titlen "Lessons" of the Past; The Use and Misuse of History in American Foreign Policy (London: Oxford University Press, 1973). Her belyste han, hvordan amerikanske præsidenter og rådgiverne omkring dem i en række kriser havde forsøgt at forstå udenrigspolitiske problemer ved at finde og analysere passende historiske analogier. Det var Mays generelle indtryk, at disse beslutningstagere som regel brugte historiske erfaringer dårligt og sjældent ledte grundigt nok efter en passende analogi. Efter hans opfattelse var der her en oplagt opgave for professionelle historikere.

Ernest May underviste senere selv et kursus i 'anvendt historie' på Harvard University, og i 1986 skrev han sammen med politologen Richard Neustadt bogen Thinking in Time: The Uses of History for Decision Makers.

\section{Manifest for anvendt historie}

Senere døde ideen om anvendt historie lidt ud i USA, men den er fornylig blevet genoplivet af to andre Harvard-historikere, Niall Ferguson og Graham Allison. Ferguson hævder, at de fik ideen, mens han arbejdede på en biografi om tidligere udenrigsminister Henry Kissinger, og $i$ august 2016 udarbejdede de et manifest for anvendt historie.

Det opfordrede amerikanske præsidentkandidater til at oprette et råd af historikere i Det Hvide Hus efter de samme retningslinjer som det Council of Economic Advisors, der har eksisteret siden Anden Verdenskrigs afslutning. Et sådant råd skulle 'anlægge historiske perspektiver på aktuelle problemer'. Med andre ord skulle rådet systematisk afsøge passende og brugbare analogier. Ferguson og Allison citerer i deres manifest Winston Churchills dictum, at "jo længere man kan se tilbage, desto længere kan man også se frem".

Samme citat anvender historikerne Jo

Niels Bjerre-Poulsen er lektor ved Institut for Historie, Syddansk Universitet. 
Guldi og David Armitage også i det manifest, de udgav for et par år siden: The History Manifesto (Cambridge: Cambridge University Press, 2014). Også her er det erklærede formål at promovere historikernes relevans i en tid, hvor de humanistiske discipliner er under politisk pres for at demonstrere deres nytteværdi. Guldi og Armitage fremhæver især historikernes evne til at placere begivenheder og deres konsekvenser i et længere tidsperspektiv, hvilket de hævder kan danne grundlaget for bedre politiske beslutninger.

Den slags er jo sød musik i mange historikeres ører. Tænk, hvis et sådant råd af dygtige historikere havde et mandat til eksempelvis at forhindre uigennemtænkte militære interventioner. Tænk, hvis det kunne havde gjort præsident George W. Bush opmærksom på, at der var voldsomme historisk betingede spændinger mellem sunnimuslimer og shiamuslimer i Irak, og at man i den forbindelse burde overveje, om et regimeskifte udefra nu også var en god ide. Og tænk, hvis det tilmed havde fået præsident Bush og hans nærmeste rådgivere til at ændre deres planer.

Guldi og Armitage taler også om nødvendigheden af, at historikere påtager sig ansvaret for at tale magten midt imod 'speak truth to power' - men deres erklærede mål er tydeligvis at gøre historiske erfaringer mere anvendelige for de selv samme magthavere, de skal tale imod. Spørgsmålet er, hvor ofte de to målsætninger i praksis er forenelige.

\section{Historikere som vismænd?}

Op gennem tiderne kan vi finde adskillige eksempler på historikere, der har anvendt deres viden mere instrumentelt. Man kan også pege på andre lande end USA, hvor regeringer har bestræbt sig på i højere grad at inddrage faghistorikere i den politiske beslutningsproces. Et nyligt eksempel er de ansatte historikere i Storbritanniens Foreign and Commonwealth Office, som udenrigsminister William Hague i 2012 - både i bogstavelig og symbolsk forstand - hentede op fra kælderlokaler og placerede i ministeriets hovedbygning $\mathrm{i}$ Whitehall.

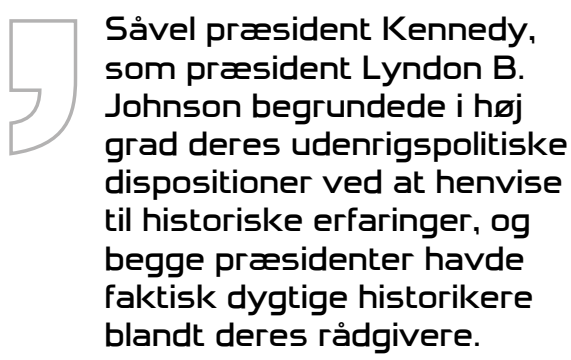

Spørgsmålet er dog i hvilket omfang, det er en realistisk karrieremulighed for historikere at fungere som vismænd for magtfulde politikere og guide dem til fornuftige udenrigspolitiske valg? I hvilket omfang er magthavere, når det kommer til stykket, villige til at høre på - endsige rette sig efter - historikere, der taler dem midt imod i vitale sikkerhedspolitiske spørgsmål? Efter nogle års arbejde med Vietnamkrigens historie, herunder præsident John F. Kennedys og præsident Lyndon B. Johnsons beslutninger om at optrappe USA's militære engagement $\mathrm{i}$ krigen, er jeg skeptisk over for ideen om at formalisere historikeres rolle som politiske rådgivere. Lad mig give nogle eksempler på, hvordan historien og historikere blev anvendt i Det Hvide Hus i de år:

Såvel præsident Kennedy, som præsident Lyndon B. Johnson begrundede i høj grad deres udenrigspolitiske dispositioner ved at henvise til historiske erfaringer, og begge præsidenter havde faktisk dygtige historikere blandt deres rådgive- 
re. En af dem var Arthur M. Schlesinger, Jr., der blev en slags hofhistoriker for Kennedy. Han bemærkede engang, at George Santayanas aforisme om at være dømt til at gentage historien, hvis man ikke kendte den burde vendes om: "Alt for ofte er det dem, der faktisk kan huske fortiden, der er dømt til at gentage den", påpegede Schlesinger.

Var der en skelsættende begivenhed, som både Kennedy og Johnson kunne huske og ofte vendte tilbage til, så var det den aftale, som Storbritanniens premierminister Neville Chamberlains og Frankrigs Édouard Daladier i efteråret 1938 indgik med Adolf Hitler og Benito Mussolini i München - en aftale, hvor Storbritannien og Frankrig accepterede, at Nazi-Tyskland annekterede Sudeterland. Resten er, som man siger, historie, og 'München' blev siden et billede på, hvad Pentagon-strategen Dr. Fritz Kraemer engang kaldte 'provokerende svaghed'.

\section{München-analogien}

Beslutningstagere leder som regel efter to forskellige sæt af historiske analogier: De forsøger både at kortlægge konsekvenserne af at handle og konsekvenserne af ikke at handle. Når det gælder sidstnævnte kategori - undladelsessynderne - så blev München-aftalen den hyppigst anvendte historiske analogi i efterkrigstidens USA. Under den Kolde Krig var det en grundlæggende antagelse, at Sovjetunionens ekspansion havde den samme grundlæggende dynamik, som Nazi-Tysklands i 1930'erne. Begge regimer var totalitære og blev derfor set som ekspansive af natur. Lokale konflikter blev betragtet som dele af en større samlet plan, og en 'tilpasningspolitik' i disse konflikter ville blot fremskynde den fortsatte ekspansion.

Præsident Harry S. Truman (1945-
1953) beskrev i sine memoirer, hvordan han havde trænet sig selv $i$ at se tilbage $i$ historien for at lede efter fortilfælde for de problemer, han blev stillet overfor. Han var overbevist om, at sådanne fortilfælde udgjorde det bedste beslutningsgrundlag, og var der én krystalklar lære at uddrage af 1930'erne, så var det efter hans opfattelse, at tilpasningspolitik førte til krig, og at man derfor hellere måtte sætte hårdt mod hårdt tidligt, fordi problemet ellers blot ville vokse yderligere.

Samtidig med, at Frankrig stod til at lide sit afgørende nederlag i sin krig mod Viet Minh i Vietnam, lancerede Trumans efterfølger på præsidentposten Dwight $\mathrm{D}$. Eisenhower i en tale den 7. april 1954 den såkaldte domino-teori. Teorien lå i direkte forlængelse af München-analogien.

Selve ideen om, at en konflikt i ét land kunne sprede sig og destabilisere nabolandene var selvfølgelig ikke ny, men Eisenhowers tale var med til at ophøje denne risiko til et princip: En trussel mod ét land $i$ en region var en trussel mod hele regionen, og i sidste ende en trussel mod USA's nationale sikkerhed. Den svenske historiker Göran Rystad har under ét beskrevet München-analogien og domino-teorien som 'München-syndromet'.

Dette syndrom var også, hvad præsident Lyndon B. Johnson hyppigst henholdt sig til, når han skulle begrunde sin optrapning af USA's militære engagement i Vietnam. Et nederlag her ville "opmuntre og anspore dem, der forsøger at erobre alle frie nationer inden for deres rækkevidde", fortalte Johnson offentligheden, da han i marts 1965 sendte amerikanske tropper til landet, og han fortsatte: "Dette er vor tids klareste lære. Fra München og til i dag har vi lært, at bøjer man sig for aggression, så fører det kun til endnu større trusler”.

München var ligeledes den foretruk- 
ne analogi for de fleste af præsidentens ministre og rådgivere. Da udenrigsminister Dean Rusk i marts 1965 i en tale til Chamber of Commerce skulle begrunde behovet for at sende amerikanske landtropper til Vietnam sagde han:

“... Så hvad er der på spil? Hvad er vores forpligtelse i den situation? Kan vi her i dette rum glemme den lektie, vi lærte om krig og fred, da der kun gik 10 år fra annekteringen af Manchuriet til [angrebet på] Pearl Harbor; og omkring to år fra annekteringen af Tjekkoslovakiet til Anden Verdenskrigs udbrud i Vesteuropa? ... Vi lærte, at ved at udskyde spørgsmålet, blev resultatet kun mere frygteligt, holocaust mere forfærdeligt. Vi kan ikke glemme den erfaring."

\section{$\square$ “Dette er vor tids klareste lære. Fra München og til i dag har vi lært, at bøjer man sig for aggression, så fører det kun til endnu større trusler".}

Dean Rusk bevægede sig her fra den konkrete historiske parallel til en mere principiel betragtning om totalitære styrers forventede adfærd. Som han selv påpegede det $i$ en anden tale, var Mao og Ho Chi Minh ganske vist ikke Hitler og Mussolini, men derfor burde man alligevel "ikke glemme, hvad vi har lært om aggressionens anatomi og fysiologi”.

\section{Johnsons paralleller}

München-syndromet var ikke Lyndon B. Johnsons eneste historiske pejlemærke i optrapningen af den militære indsats i Vietnam. Han var generelt mere interesseret $i$ indenrigspolitik end i udenrigspolitik, men frygtede, at et udenrigspolitisk nederlag - ikke mindst et sydvietnamesisk kollaps - ville spænde ben for hans hjem- lige politiske visioner. Den frygt begrundede han først og fremmest ved at henvise til sin forgænger præsident Harry S. Trumans politiske skæbne. Den havde tidligt i hans egen politiske karriere gjort et stort indtryk på ham. Måske var Johnson særligt opmærksom på historiske paralleller fordi også han, som Truman, var blevet præsident, da en populær forgænger døde i embedet (i Trumans tilfælde Franklin D. Roosevelt, i Johnsons tilfælde John F. Kennedy).

Fra det øjeblik Lyndon Johnson blev svoret ind som præsident efter mordet på John F. Kennedy i Dallas den 22. november 1963, overfortolkede han efter alt at dømme parallellerne til præsident Trumans situation. Blot nogle få timer efter sin tiltrædelse erklærede han: "Jeg vil ikke tabe Vietnam. Jeg vil ikke være den præsident, der ser Sydøstasien gå samme vej som Kina”.

Han så tilbage på de heftige politiske diskussioner i 1949 om 'tabet af Kina', og han mindedes, hvordan Republikanerne efterfølgende havde brugt påstået svaghed på den internationale scene som et påskud for at bremse Trumans hjemlige politiske reformprogram, the Fair Deal, i Kongressen.

Sammen med Sovjetunionens udvikling af en atombombe og Nordkoreas angreb på Sydkorea havde 'tabet af Kina' også banet vejen for den kommunistforskrækkelse, der i 1950'erne blev kendt som McCarthyismen (efter Senator Joe McCarthy fra Wisconsin). Johnson frygtede, at en lignende højredrejning kunne ske igen, hvis et udenrigspolitisk nederlag gav Republikanerne en anledning til at angribe hans hjemlige reformer.

Som Johnson senere udtrykte det til en af sine rådgivere, George Ball: "George, du skal ikke tage dig af, hvad de små skide- 
Som Johnson senere udtrykte det til en af sine rådgivere, George Ball: “George, du skal ikke tage dig af, hvad de små skiderikker på universiteterne foretager sig. Det store uhyre er de reaktionære elementer i dette land. Det er de mennesker, vi har grund til at frygte"

rikker på universiteterne foretager sig. Det store uhyre er de reaktionære elementer i dette land. Det er de mennesker, vi har grund til at frygte".

At Neville Chamberlains skæbnesvangre møde i München, samt mindet om præsident Trumans skæbne var de to historiske analogier, som Lyndon B. Johnson mere end noget andet lod sig motivere af, fremgår tydeligt af hans erindringsbog Vantage Point fra 1971. Her skriver han blandt andet:

“... Alt hvad jeg vidste om historie sagde mig, at hvis jeg trak mig ud af Vietnam og lod Ho Chi Minh løbe gennem Saigons gader, så ville jeg havde gjort nøjagtigt, hvad [Neville] Chamberlain gjorde i Anden Verdenskrig. Jeg ville have givet en stor fed belønning til aggression. Og jeg vidste, at hvis jeg lod den kommunistiske aggression føre til erobringen af Sydvietnam, så ville der i dette land [USA] følge en endeløs national debat - en ondskabsfuld og destruktiv debat - der ville tilintetgøre mit præsidentembede, tage livet af min regering og skade vort demokrati. Jeg vidste, at Harry S. Truman og Dean Acheson havde mistet deres effektivitet fra den dag, hvor kommunisterne tog magten i Kina. Jeg var overbevist om, at tabet af Kina havde spillet en stor rolle i Joe McCarthys politiske opstigning, og jeg vidste, at alle disse problemer, samlet under et, var det rene kyllingelort sammenlignet med, hvad der kunne ske, hvis vi mistede Vietnam."

\section{Amerikansk exceptionalisme}

Hvis 'München-syndromet' tilsagde, at USA om nødvendigt måtte gribe mi- litært ind og forhindre en kommunistisk magtovertagelse i Vietnam, så ledte man i Washington også efter relevante historiske eksempler på, hvordan det konkret kunne gøres - og måske lige så væsentligt, hvordan det ikke skulle gøres. I begyndelsen af 1960'erne studerede amerikanske beslutningstagere både franskmændenes erfaringer i Vietnam og briternes erfaringer i Malaya. Deres søgen efter analogier var dog ofte selektiv, og negative erfaringer blev oftest overtrumfet af en følelse af amerikansk 'exceptionalisme'.

Man så med velvilje på briternes erfaringer med oprørsbekæmpelse i Malaya, først og fremmest fordi det rent faktisk var lykkedes dem at nedkæmpe oprørerne. Hvad præsident Kennedy hæftede sig ved var, at Storbritannien havde gennemført omfattende økonomiske reformer og kombineret dem med en resolut militær indgriben med specialstyrker, der kun satte et lille 'fodaftryk' i landet.

Hvad præsidenten derimod gik let henover var, at det havde taget 80.000 britiske soldater og dobbelt så mange indfødte tropper 13 år at nedkæmpe en oprørsstyrke på omkring 10.000 mand. Oprørsbevægelsen FNL (Viet Cong) i Sydvietnam havde langt flere partisaner til rådighed. Kennedy og hans rådgivere ignorerede også, at oprørerne i Malaya af flere grunde - blandt andet den omstændighed at de var etniske kinesere - havde været nemme at adskille fra den øvrige befolkning. Rent logistisk havde det også været langt nemmere at bremse forsyninger til dem, end tilfældet var i Vietnam.

Et vigtigt element i oprørsbekæmpel- 
sen i Malaya havde været opførelsen af såkaldte strategiske landsbyer, der kunne holde oprørerne ude. For at kunne trække direkte på disse positive erfaringer, inviterede den amerikanske regering derfor selve ophavsmanden til denne politik, Sir Robert Thompson, til Sydvietnam som rådgiver. Der var dog en afgørende forskel på omstændighederne i de to lande: I Malaya havde landsbyerne haft til formål at beskytte malayer mod de etnisk kinesiske oprørere. I Sydvietnam derimod var der ofte svært at finde ud af, hvem det var, man beskyttede mod hvem, og det var umuligt for myndighederne at vide, om FNL allerede var inden for landsbyernes palisader eller ej.

Omstændigheder af denne art slog dog sjældent folkene omkring præsident Kennedy ud, for de kunne altid vælge at henholde sig til, at USA militært og økonomisk var i en klasse for sig. Når det kom til stykket, trumfede exceptionalismen de historiske erfaringer.

Dette var også reaktionen hos præsident Johnsons nationale sikkerhedsrådgiver, McGeorge Bundy, da den franske udenrigsminister Maurice Couve de Murville i 1965 fortalte ham om franske erfaringer i Indokina og Algeriet og hævdede, at USA ikke kunne undgå et nederlag i Vietnam. Det udsagn fik blot McGeorge Bundy til at trække på skuldrene, for, som han efterfølgende sagde til præsident Johnson, var det "af indlysende grunde en trøsterig konklusion for en franskmand".

Bundys arrogante afvisning afspejlede en udbredt mistillid i Washington til Frankrigs militære og logistiske formåen. En talsmand for de militære stabschefer havde året før grebet endnu længere tilbage i historien efter argumenter: Franskmændene havde måttet opgive at bygge Panama-kanalen, påpegede han, mens amerikanerne havde gennemført projektet.

Der fandtes rådgivere både i Udenrigsministeriet og i Det Hvide Hus, som vedvarende advarede om, at USA kunne komme til at lide samme skæbne, som Frankrig havde gjort i Vietnam, men disse var i klart mindretal. Viceforsvarsminister John McNaughton advarede ligefrem imod, hvad han kaldte 'French-defeat syndrome' - angiveligt en tilstand, hvor man lod sig hæmme af bevidstheden om, at Frankrig havde tabt krigen i Vietnam. Han og andre rådgivere pegede blandt andet på, at Frankrig trods løfter om politiske reformer og øget selvstyre aldrig havde været i stand til at frigøre sig for rollen som forhadt kolonimagt. USA havde efter hans mening helt andre betingelser for at vinde 'hjerter og sind' i landet.

Forsvarsminister Robert S. McNamara var i midten af 1960'erne angiveligt stolt over, at krigen i Vietnam blev omtalt som 'McNamaras krig. To årtier senere så han den imidlertid som en tragisk fejltagelse, der først og fremmest måtte tilskrives, at de amerikanske beslutningstagere havde vidst for lidt om Vietnamesisk historie og kultur.

\section{Rådgiverne}

Det er sandt, at der manglede viden om vietnamesisk kultur, men generel faghistorisk viden var der ikke mangel på - hverken i Kennedy-regeringen eller i Johnson-regeringen. Mens Kennedy havde Arthur M. Schlesinger blandt sine rådgivere, så havde Lyndon B. Johnson blandt andre Eric F. Goldman, der var professor i historie ved Princeton University og tilmed beklædte posten som præsident for Society of American Historians. Kenne- 
dys stab talte også superhøgen Walt W. Rostow, der først havde været professor i amerikansk historie ved Cambridge University og siden professor i økonomisk historie ved M.I.T.

Det taler faktisk til Kennedys fordel, at han ikke lod sig imponere og overtale af Rostow, der besad en uforbeholden tro på, at mere amerikansk militær var løsningen på de fleste internationale problemer. Her var en økonomisk historiker, der mindre end et år efter, at han havde forladt sin stilling som professor, nu talte med den største selvfølgelighed om at bruge atomvåben både i Centraleuropa og i Sydøstasien.

Det blev hurtigt for meget for Kennedy, der i november 1961 fik Rostow forflyttet fra Det Hvide Hus til et nyt job i Policy Planning Council i Udenrigsministeriet. Over for Michael Forrestal, der var medlem af Det Nationale Sikkerhedsråd, begrundede præsidenten selv beslutningen med, at: "Walt er et springvand af ideer, og måske én ud af ti er aldeles fremragende. Desværre er seks eller syv af dem ikke alene ufornuftige, men tilmed farlige. Jeg beundrer hans kreativitet, men det vil være mere betryggende at have ham til at udfolde den et stykke fra Det Hvide Hus".

Gjorde Kennedy klogt i ikke at lade sig besnakke af Rostow, så kunne både han og Johnson til gengæld med fordel have lyttet mere til viceudenrigsminister George Ball, der ofte var henvist til en nærmest ceremoniel rolle som 'Rasmus modsat' blandt præsidentens rådgivere. På et møde i det Nationale Sikkerhedsråd i november 1961 advarede han eksempelvis Kennedy om, at topografien i Vietnam var totalt uegnet til det amerikanske militær, og at USA, hvis præsidenten besluttede at indsætte amerikanske landtropper, ville risikere, "at vi, inden der er gået fem år, har
300.000 mand ude i rismarkerne i Vietnams jungler og er ude af stand til at finde dem igen". Nok havde Kennedy selv sine forbehold over for at sende landtropper, men Balls vurdering syntes han alligevel var for langt ude: "Ja, George, du siges jo at være en af de klogeste fyre i byen", sagde han grinende, "men du er skør som ind i helvede! Det vil aldrig ske!" (i 1967 passerede antallet af amerikanske soldater i Vietnam 500.000).

Man må med skuffelse konstatere, at det ikke altid var faghistorikerne, der gav præsidenterne de mest velunderbyggede råd, men vi kan godt finde eksempler på gode beslutninger, som historikerne i staben af rådgivere havde konkret indflydelse på. En af dem er Kennedys accept af, at Laos i 1961 fik neutral status under en samlingsregering, hvor også kommunisterne fra Pathet Lao var repræsenteret.

Flere af præsidentens rådgivere havde ellers fastholdt, at den slags regeringer altid førte til, at kommunisterne før eller siden tog magten, men Arthur M. Schlesinger, Jr. fik angiveligt Kennedy til at acceptere en neutralisering af landet, blandt andet ved at henvise til Italien og Frankrig, hvor kommunisterne var kommet med i samlingsregeringer uden at kuppe sig til magten. Her anvendte Arthur M. Schlesinger, Jr. med held sin historiske viden til at få medhold.

At ikke alle rådgivere vandt samme lydhørhed i Udenrigsministeriet og Det Hvide Hus, vidner Paul Kattenburgs skæbne om. Han var det amerikanske Udenrigsministeriums førende Vietnam-ekspert. Han havde en ph.d.-grad i international politik fra Yale, og han havde i en stor del af 1950'erne opholdt sig i Sydøstasien. Under præsident Kennedy blev han formand for den såkaldte Vietnam Working Group. Et møde i det Nationale Sikkerhedsråd, 
den 31. august 1963, blev imidlertid skæbnesvangert for Kattenburgs videre diplomatiske karriere. Her fortalte han nemlig som den første præsidenten, at denne burde benytte den aktuelle krise i Saigon til at trække USA helt ud af Vietnam. Kattenburg, der havde kendt Sydvietnams præsident Diem i ti år, mente, at denne havde udviklet sig til en småtskåren diktator, der aldrig ville gennemføre de demokratiske og økonomiske reformer, den amerikanske regering fandt nødvendige for at sikre et selvstændigt Sydvietnam. Derfor ville det efter hans mening være den mindst dårlige løsning at sikre Vietnam samme neutrale status som Laos og derefter komme ud i en fart. Dette var også, hvad eksempelvis Frankrigs general de Gaulle havde foreslået samme år.

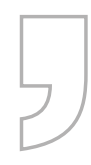

\section{Måske er historikere sjældent i deres rette ele- ment, når de forventes at in- strumentalisere deres viden og rette den mod et konkret politisk mål.}

Argumenterne faldt hverken i god jord hos Kennedy eller i resten af kredsen omkring ham. Henvisningen til de Gaulle gjorde næppe sagen bedre. Nogle måneder senere blev Kattenburg overflyttet til arbejde, der ikke havde med den overordnede planlægning af krigsindsatsen i Sydøstasien at gøre. Dermed sluttede hans karrieres deroute dog ikke: Snart blev han sendt videre til en diplomatpost i Guyana. Hans pessimisme havde gjort præsidenten en bjørnetjeneste, lød begrundelsen, og det kom til at vare længe, før nogen igen fulgte hans eksempel med åbent at tale om alternativer til den eksisterende kurs.

Seksten år senere så Kattenburg tilbage på det skæbnesvangre møde og mindedes, at der ikke var en eneste af de øvrige tilste- deværende deltagere, som vidste, hvad de talte om. De kendte hverken Vietnam eller dets historie, mente han.

Skal man tro Harvard-historikere James C. Thomson, Jr., der også i en årrække arbejdede med sikkerhedspolitik i Østasien for både Kennedy og Johnson, så havde hovedparten af de medarbejdere, der virkelig vidste nogen om forholdene i Indokina, forladt Udenrigsministeriet og Pentagon i første halvdel af 1960'erne. Når det gjaldt mulighederne for at forsvare et selvstændigt Sydvietnam, havde de typisk været blandt de mest pessimistiske i staben, og de var ofte blevet erstattet af folk, der som det hedder på moderne dansk - havde 'ja-hatten' på.

\section{En unyttig analogi}

Det giver anledning til at gøre sig nogle mere generelle overvejelser om ideen med 'anvendt historie'. Måske er historikere sjældent i deres rette element, når de forventes at instrumentalisere deres viden og rette den mod et konkret politisk mål. Hvor meget det end ville stimulere vores faglige stolthed, så er der ikke belæg for at tilskrive USA's ulykkelige krigsførelse i Vietnam et fravær af dygtige faghistorikere i beslutningsprocessen.

En manglende historisk bevidsthed hos politikerne synes heller ikke at have været hovedproblemet - nærmest tværtimod. Om noget, så havde præsident Johnson snarere lært for meget - eller i hvert fald det forkerte - af historien.

Da det kom til stykket væltede dominoerne ikke i resten af Sydøstasien ved Saigons fald i 1975. I Laos og Cambodja gjorde de ganske vist, men det var ironisk nok, fordi selve krigen i Vietnam havde bredt sig til disse formelt neutrale lande. I regionens øvrige lande, heriblandt Thailand, Burma, Indonesien og Filippinerne, 
blev regeringerne derimod ikke undergravet som en følge af nordvietnamesernes sejr. Dominoerne faldt heller ikke i Europa, og skaderne på USA's troværdighed som supermagt var begrænsede.

'München' viste sig med andre ord ikke at være nogen nyttig analogi. Den havde blot fået de amerikanske beslutningstagere til at tage sig selv som gidsler og hævde, at supermagtens globale troværdighed afhang af Vietnamkrigens udfald. Det gjorde den tydeligvis ikke, da det kom til stykket.

Nok var supermagtens selvfølelse såret, men hos de fleste allierede var reaktionen på nederlaget mest en slags lettelse over, at krigen omsider var slut. Trods europæiske demonstranters skilte med 'Yankee, Go Home!', havde den største bekymring hos de europæiske politikere hele tiden været, at krigen i Vietnam kunne trække ressourcer væk fra forsvaret af Europa.

Hjemme i USA fik vietnamkrigen dog konsekvenser. En af dem var, at den undergravede det økonomiske fundament for præsident Johnsons store hjemlige reformprogram, 'Great Society'. En anden var, at bestræbelserne på at skjule krigens reelle omkostninger i sidste ende blot havde øget den generelle mistillid til hele det politiske system. For præsident Johnson personligt fik den selvfølgelig også tragiske konsekvenser. Han blev ikke, som han selv frygtede, husket som en ny Neville Chamberlain, men derimod som en mand der af overdreven frygt for at blive netop dét havde sat sit eget politiske projekt over styr.

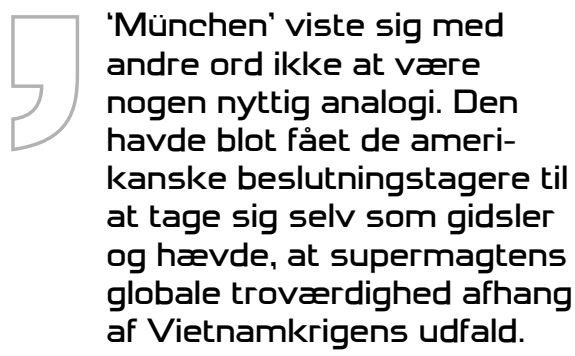

'München-analogien' lever fortsat, men mest som et retorisk greb. Der har trods alt været relativt få konflikter i de mellemliggende årtier, hvor den historiske parallel til Nazi-Tysklands angreb på Tjekkoslovakiet var oplagt (Saddam Husseins invasion af Kuwait i 1991 er dog blandt dem). Det er i højere grad krigen i Vietnam, der er blevet en passende analogi for efterfølgende konflikter og har dannet rammen om nye historiske 'lektioner'.

Til forskel fra 'München' har der dog været tale om en omvendt brug af historien. Målet med det historiske tilbageblik på Vietnamkrigen har typisk været at finde forskelle snarere end ligheder. For at vinde opbakning til brugen af militær magt har amerikanske ledere nemlig som det første måttet begrunde, hvorfor Vietnam ikke var en passende historisk parallel. 